UDC 378.09:37.063-028:004

DOI https://doi.org/10.30839/2072-7941.2018.155560

\title{
ELECTRONIC PORTFOLIO AS A MEANS OF SUCCESSFUL EMPLOYMENT OF GRADUATES OF PEDAGOGICAL PROFILE
}

\author{
C) SAIAPINA, S. A. \\ SHEI "Donbas State Pedagogical University" (Sloviansk, Ukraine) \\ E-mail: sayapina.s.a.2018@gmail.com, ORCID ID 0000-0001-5808-7020 \\ (C) KORKISHKO, O. H. \\ SHEI "Donbas State Pedagogical University, (Sloviansk, Ukraine) \\ E-mail: korkishko.l.g@gmail.com, ORCID ID 0000-0001-7341-2610
}

\begin{abstract}
The paper presents the problem of developing and using the electronic portfolio of the future pedagogue from the point of view of its influence on his/her successful employment. It is proved the relevance of its being used for correct self-advertising by future professionals of pedagogical profile at the modern labour market that contributes to increasing the competitiveness and motivation for employment in the speciality. It is determined that the e-portfolio can serve as an instrument for measuring the quality of training a future specialist by means of his/her quantitative evaluation (participation in research work, scientific and practical conferences of various levels, competitions on subjects, contests of scientific papers and works, public life at higher educational institutions, towns and cities; printed and electronic publications, etc.) and high-quality (fellow students' and lecturers' reviews, letters of recommendation, letters of commendation, references of supervisors of practice and administration of the educational institution, rating of the success of the training, etc.) results of his/her activities. It is shown that for successful employment of the graduates the most effective is the so-called integrated e-portfolio that is the set of different blocks, such as general information about the student; portrait of a pedagogue; achievements; social activities; evaluation and comments. It is accentuated that the student's e-portfolio makes it possible the following: introducing the information on participation in research-scientific work, learning and upbringing activities of the university; visualising the submitted information; reflecting the examples of his/her own activities, illustrating the process of performing this or that work; monitoring the results of the work performed.
\end{abstract}

Key words: e-portfolio; employment; student; future master; pedagogical profile; faculty.

The problem in general terms and its connection with important scientific or practical tasks. Relevance of research topic. One of the promising areas of the youths' being involved in the country's social processes is providing them with jobs. Under the conditions of the market economy, the right to work is realised through social guarantees and personal initiative. In recent years, the problem of employment of graduates of higher educational institutions is particularly urgent. According to the experts from the labour market (O. Krasnoshchok, N. Matsipura, S. Nikolaienko, etc.), the situation of employment for young specialists has become more complicated. And this is due to the fact that jobs in the country as a whole are less as well those ones with official employment. As 
I. Hrabovets notes, the main obstacle for young people's employment after graduating from higher educational institutions is the lack of practical experience in the profession, shortcomings in professional orientation and preparation, too high demands of young people concerning the conditions and content of their work, etc. [7, pp. $78-79]$. Also, the problem with the employment of young people who are looking for their first job, often losing faith in the opportunity to work in a speciality, is particularly acute.

Among the main causes of complicating the employment of graduates of higher educational institutions, the following ones should be specified:

- disproportions of the structure of demand at the labour market, which become deepened due to the weak coordination links between the labour market and the market for educational services;

- mismatch of the received speciality to the needs of the labour market;

- lack of long-term economic forecasts of changes in the professional qualification structure of the workforce;

- increase competition in the labour market of professions and specialities, which are being trained at educational institutions;

- a largely unconscious approach to choosing a future profession as a result of the imperfection of the existing system of vocational guidance for young people, the focus on obtaining a prestigious (up-to-date) profession, which may not be demanded at the labour market in the long run;

- insufficiency of practical experience or experience work period in the speciality;

- gap between the content of education and the requirements of employers;

- psychological unpreparedness of young people to making independent decisions [10, p. 59].

Interest in the problem of employment is connected with the rapid socio-economic and technological changes. Graduates of higher educational institutions need skills and abilities for their effective job search. Such an instrument for active job search is self-presentation the ability to present oneself in different situations, to create a unique image.

Relying on the scientific achievements of the well-known scholars who have studied the methods of job search (O. Balakirieva, V. Vasylchenko, D. Dmytruk, E. Zeier, A. Yatsenko etc.), it should be noted that the peculiarities of selfpresentation of graduates of the pedagogical profile using their eportfolios have not been the subject of scientific investigations.

But, on the other hand, modern technologies, Internet networks give a chance to young specialists to discover new ways of employment in the speciality. One can see such opportunities in using the electronic portfolio (hereinafter e-portfolio), which will allow not only to increase the professional status, the image of the future pedagogue, but also to 
attract the young qualified personnel to the educational institutions. After all, in order to fulfil the key issues that are dictated by the current reform of the sphere, highly qualified specialists who are capable of non-standard problem solving, generating new ideas and introducing the latest technologies are urgently needed.

Research Problem Focus. The concept of "portfolio" came in our language from Western Europe in the $15^{\text {th }}-16^{\text {th }}$ centuries. Artists and architects presented their customers with finished works and sketches in a special folder, which they called "portfolio". The documents presented in this folder, allowed to make an opinion on the quality of work, to assess the professional level of applicants [11]. The first attempts concerning theoretical justification for using the portfolio technology in the sphere of education were actively used in the United States in the 80s of the $20^{\text {th }}$ century. At the end of the $20^{\text {th }}$ century, the technology of portfolio application became popular in many developed countries of the world, and at the beginning of the $21^{\text {st }}$ century it has become widespread in Ukraine [9].

"Portfolio" translated from French (from Fr. porter - to lay out, to formulate, to carry and folio - a sheet of paper, a page) means a dossier, a collection of achievements, a fixation of successes; from English (from portfolio) "portfolio" means a "briefcase", a "folder" for important documents; from Italian - a "folder with documents", a "specialist folder" [4]. In scientific publications and materials of the Internet one can come across the following terms related to the electronic portfolio, such as: "digital portfolio", "electronic portfolio", "e-portfolio", "webportfolio", "web based portfolio", "eFolio", "online-portfolio". The scientific-pedagogical sources and dictionaries interpret the concept of "e-portfolio" as:

- a unique modern electronic technology by means of which one can accumulate information about one's own achievements, skills, abilities, competences, starting from high school, continuing at university, later using during one's employment and career development throughout one's life [14];

- a differentiated collection of informational materials that reflect achievements over a continuous period of time [2];

- a model of authentic assessment which is more than traditional aimed at identifying of: an objectively available level of skills and abilities; gaps in preparation; difficulties of assimilation; the level of the skills formed and their being improved through introducing correction in the educational process; positive motives for learning; interest in the subject; development of mental activity; critical attitude to learning activities [6].

It should be noted that the eportfolio can be an instrument for demonstrating potential creative opportunities, evaluating the professional and personal growth of a specialist, the experience gained. Taking into account this fact, the task emerges concerning the future 
pedagogues' mastering and using the e-portfolio during the process of their study at universities for recording, accumulating works and documents, which links certain aspects of their activities into a more systematic and complete picture and is an effective form of evaluation of the results of their vocational training.

Analysis of recent research and publications. Over the past decades in scientific national and foreign literature, much attention has been paid to the problem of using the e-portfolio, which is considered from different angles. Today there is a multifaceted palette of views of modern scholars, scientists, researchers on the problem of using the e-portfolio by pedagogues and future pedagogues:

- the teacher's e-portfolio (S. Vasylieva, L. Hryzun, K. Kosova, T. Makarova, V. Makarov, etc.). L. Hryzun notes that the portfolio at the same time is a means of pedagogical diagnostics, a method for assessing professionalism of teachers and allows one to take into account the results achieved by the teacher in a variety of activities: educational, upbringing, creative, methodological, research ones [8];

- the lecturer's e-portfolio (L. Varchenko-Trotsenko,

V. Kyrychenko, I. Kuzmenchuk, N. Morze, etc.). N. Morze and L. Varchenko-Trotsenko review using the e-portfolio in terms of measuring the lecturer's activity results through his/her own reflection and openness [12];

- the future pedagogue's (student's) e-portfolio (T. Bruner,
N. Zhytienova, O. Ivanova, O. Linova, A. Sazonova, I. Uchytel, O. Shevchenko, etc.). For example, N. Zhytienova notes that the e-portfolio reflects concrete achievements and the most significant results achieved by the student in a variety of activities: learning, scientific-research, extracurricular (public, cultural and creative, sports, etc.) [16].

Consequently, the scientists have come to understand the e-portfolio of the future pedagogue differently, but among the essential characteristics they single out the following ones: the ability to demonstrate the strengths of the student's personality, to reveal his/her creativity as much as possible; the developed skill of analysis of activity, self-organisation, self-control, self-esteem, self-criticism, as well as reflection of educational activity; the direction of self-knowledge and understanding of the dynamics of their results and achievements [5, p. 355]; developed critical thinking and responsibility, promoting a better understanding of his/her own strengths and weaknesses, mastering the ability to set goals, to become active, independent and self-regulated $[1, \mathrm{p}$. 156]. The issue of using the e-portfolio remains relevant, and it will facilitate the successful work placement of graduates in the speciality. For employers, the e-portfolio will allow to get more comprehensive information about the professionalism of a skilled worker: it is not necessary to look for information about a worker in social networks, which can sometimes be insufficient to highlight his/her knowledge, skills, abilities in this or that professional activity. That is why it 
is precisely the e-portfolio that will help with the process of solving employment issues in the future [13].

Considering the active study of various aspects of the problem of developing and using the e-portfolio practically in the educational process of universities, there are still quite many unsolved issues: using the e-portfolio to demonstrate the dynamics of the most significant theoretical and practical products for assessing the professional competence, creating an individual portrait of future pedagogue, systematising, analysing and representing skilfully his/her professional achievements for a potential employer in education, lack of a mechanism of using the e-portfolio for a future pedagogue's being evaluated and criteria for such selection and experience.

The purpose of the paper is to analyse and characterise the potential of the e-portfolio as one of the most powerful instruments that will facilitate the employment of the graduates of the pedagogical profile by their specialities.

Presenting of the main material. The situation with the employment of graduates of universities is ambiguous. The official statistics [15] do not give a clear idea of the percentage of the graduates of higher educational institutions who cannot find work after obtaining the corresponding pedagogical level. The situation with regard to the young specialists in the pedagogical profile is complicated.

The SHEI "Donbas State Pedagogical University" (hereinafter the SHEI "DSPU") is carrying out active work on employment of the graduates in the speciality, namely:

- analyses the demand and offer at the labour market of the specialists trained at the higher education institution;

- establishes cooperation with the state employment service, institutions and organisations irrespective of the form of ownership that may be potential employers for graduates and students;

- ensures coordination of actions with central and local executive authorities, employment services, institutions and organisations (employers) in order to optimally coordinate the real needs of the labour market and the market of educational services;

- informs its graduates and students about vacancies in institutions and organisations corresponding to their professional training (speciality);

- monitors the placement of graduates by their place of residence together with the State Employment Service.

At the Faculty of Primary, Technological and Vocational Education (hereafter the Faculty of PTVE), the following scheme for interaction with the State Employment Service, educational institutions on the issues of employment of the students and graduates in the speciality (Figure 1) has been developed. 


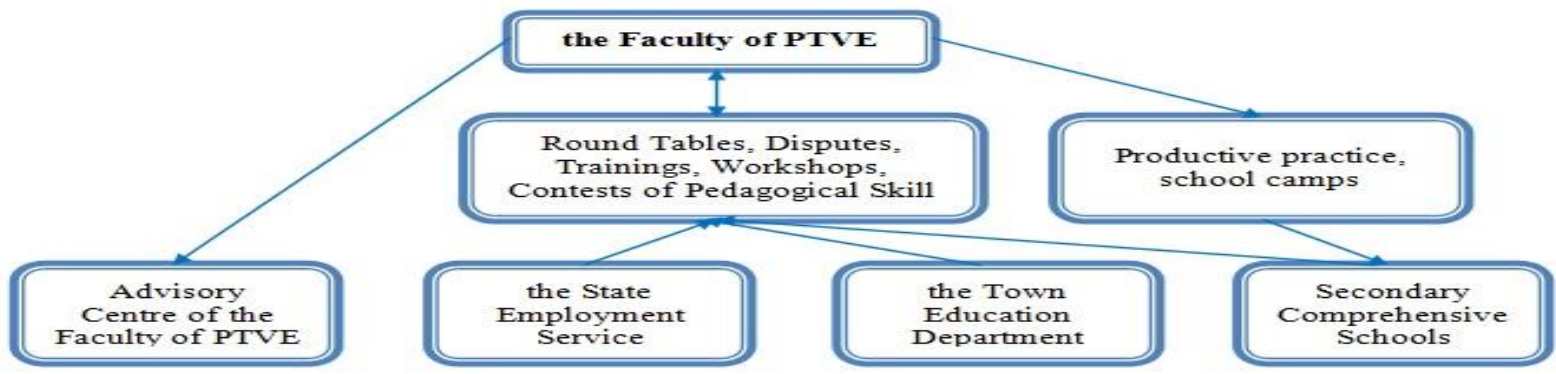

Figure 1. Scheme of Interaction of the Faculty of PTVE with the State Employment Service, Educational Institutions on the Issues of Employment of the Students and Graduates

Thus, it is necessary:

1) to establish closer coordination relations between the educational institutions and the faculty: this will be facilitated by implementing the targeted training, which involves the training of prospective future specialists on the basis of the available production capacities, their training courses without interruption from the place of studying;

2) to direct the future university graduates to search for their jobs starting this while studying at the second or third year of learning at the university: it is necessary to closely collaborate with the State Employment Service, the Town Education Department, as well as with the educational institutions that are potential employers for the university graduates;

3) to organise round tables, disputes, etc., in cooperation with the student self-government and the heads of practice bases, aimed at creating the conditions for communicating the potential employers with the students, it will enable the future pedagogue to determine in advance what he/she needs for his/her work in an educational institution or directly submit his/her resume (portfolio) to the representatives of the educational institutions;

4) to set up the production practices that are mandatory when studying at the institution of higher education so that the student during five years undergoes his/her practice in one educational institution as the place of training courses may become his/her first place of work;

5) at senior years of studying (the practice lasts for $4-6-8$ weeks) to place in his/her job officially (under the existing conditions), which will motivate taking more seriously to his/her practice, it also will give an opportunity to think about choosing a speciality, earning some pedagogical experience, to be materially interested;

6) to facilitate the employment of students (at the end of the $1^{\text {st }}$ and $2^{\text {nd }}$ year of studying) at school camps (it is possible to take part and test oneself in all types of pedagogical activities, to get practical experience, to understand the right choice of a profession, etc.);

7) to involve the potential employers in the jury of professional 
skill contests;

8) to issue letters of recommendation, references, characteristics (supported by the real achievements of the student) by the administration of the faculty or the university;

9) to create an advisory centre at the faculty:

- forming the students' and graduates' resume bank, e-portfolios;

- assisting the student in developing a job search strategy;

- conducting consultations on compiling resumes, e-portfolios, accompanying letters and letters of recommendation;

- preparing for a successful interview with the employer;

- conducting professional testing, workshops on resume writing, on compiling e-portfolios, trainings for effective job search;

- performing informational and educational activities among the students and graduates in order to promote their employment and effective career planning.

Analysing the data of modern scientific researches makes it possible to note that using the e-portfolio under the conditions of the electronic educational space or external network resource provides communication of the student and the lecturer, the representatives of the education department, the administration of the educational institution in the network is a promising form of correct selfpromotion in the open information and education environment of the higher educational institution and beyond.
The e-portfolio will serve as an instrument for measuring the quality of future specialist's training by evaluating his/her quantitative and qualitative performance indicators. The quantitative indicators of such activity can be: participating in scientific-research work, in scientific and scientific-practical conferences of various levels, in contests on subjects, in competitions of scientific works, in public life of the higher educational institution and the town; the students' printed and electronic publications, etc. The qualitative indicators include comments and opinions of fellow students and lecturers, letters of recommendation, letters of reference, references of the head of practice and administration of the educational institution, the rating of the studying success, etc.

It is well-known that using the eportfolio technology while studying at the institution of higher education enables to form a complete set of the student's achievements - records (one's formula for success, love of the profession, love for children, description of impressions from one's practical activities in educational institutions, etc.), documents (resumes, lists of awards, diplomas, letters, ratings of the studying activity, references of lecturers, certificates of passing of additional educational programs, etc.), reports (participation in scientific-research work, conferences of different levels, olympiads, professional and creative pedagogical competitions, intellectual marathons, reports in the form of slides, presentations, photos, etc.), provides a stable motivation of the 
student for professional development and self-improvement, forms the ability to self-presentation, selforganisation and correct selfpromotion, demonstrates the level of professional reflection and communicative abilities, readiness for self-realisation.

Consequently, the e-portfolio is a summation of the student's works (records, reports, documents) collected using the electronic carriers and media, either on a digital medium (a CD / DVD Disk), the so-called eportfolio, or a web-site, i. e. onlineportfolio.

The approaches to building the eportfolio, which will promote both the opportunities and the desire to work in an educational institution, can be varied depending on the individual characteristics of the student. It is important for a future pedagogue to analyse his/her own work, successes, generalise and systematise achievements, objectively evaluate his/her capabilities and see ways to achieve better results.

The e-portfolio can be created using the various applications of Windows, Linux, in particular the International Society for Technology in Education, 2012, developed the standards of the e-portfolio patterns for the formats of Microsoft Word, Microsoft Excel, Microsoft PowerPoint and HTML (Web Pages). It should be noted that the students use the eportfolio patterns in the formats of Microsoft Word and Microsoft PowerPoint more often (Figures 2 $3)$.

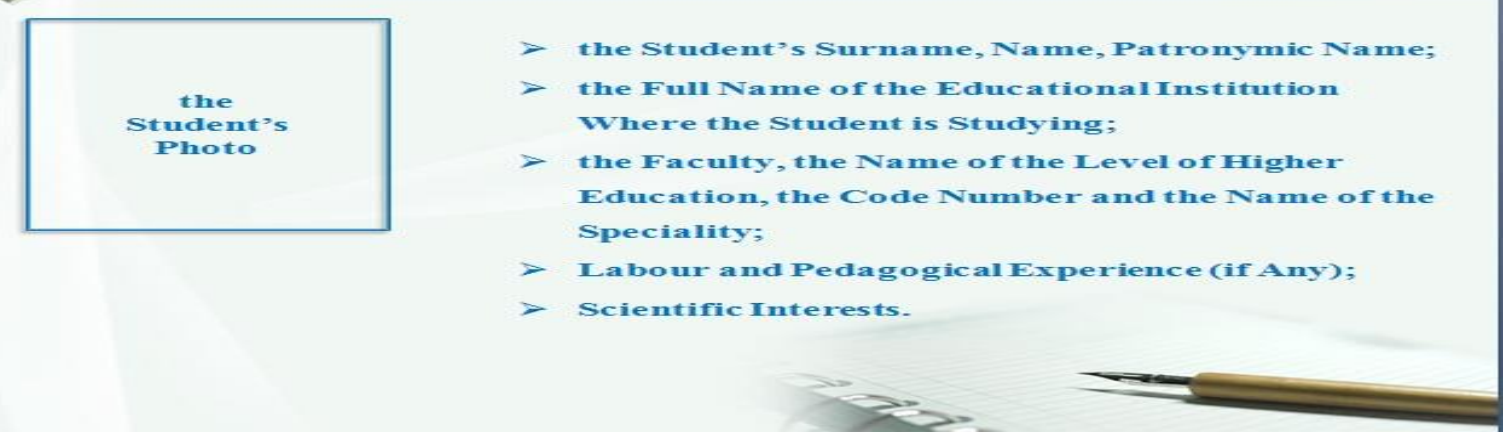

Figure 2. Sample of the E-Portfolio in the Format of Microsoft PowerPoint

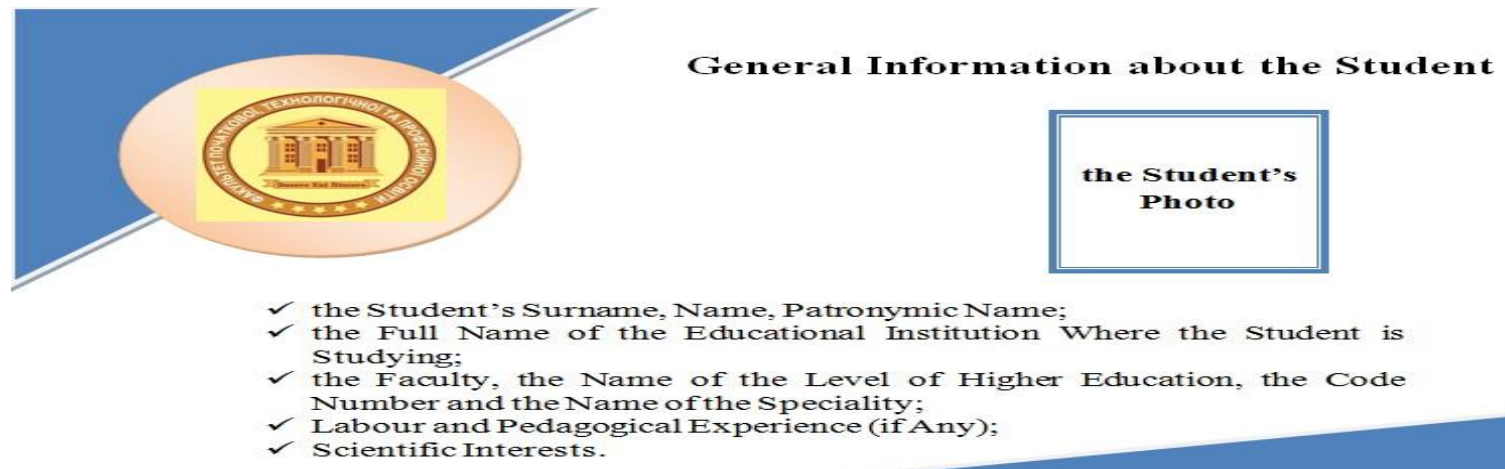

Figure 3. Sample of the E-Portfolio in the Format of Microsoft Word 
The investigator I. Filo has derived the formula that helps to understand the meaning of the concept of the eportfolio: E-Portfolio = E-Portfolio + Web Portfolio. Web Portfolios are the e-portfolio systems that are interactive and customisable through the web. Consequently, the user of the web portfolio has access to his/her electronic space from anywhere in the universe where there is the Internet access [5]. One can place there those data which cannot be shown on paper. These can be multimedia products designed for lessons or extracurricular activities; speeches at conferences of various levels, speeches at discussions, round tables, etc.; participation in cultural events concerts, clubs of the cheerful and resourceful, brain rings, holidays, etc.; awards and certificates, reviews, scientific works, projects or lecturers' comments, etc.; the blog, calendar, project management or the user's files.

The scholars and pedagoguespractitioners $\quad[5 ; 6 ; 8 ; 12 ; 16]$ distinguish the following types of the professional e-portfolio:

- the e-portfolio of the student's achievements - a set of documents informing about the successes of professional-pedagogical activity;

- $\quad$ the presentation e-portfolio correct advertising, which will promote forming the professional status, image of the pedagogue, successful employment;

- the thematic e-portfolio - a set of scientific-research, creative works, which presents the professional activity and scientific interests of the pedagogue;

- the integrated e-portfolio - a complex of all types of portfolio, aimed at a positive presentation of the pedagogue.

For the successful employment of the graduates of the pedagogical profile, the most effective is the integrated e-portfolio that makes up a set of different blocks, such as:

1. General information about the student (Form: business cars in PowerPoint):

- the photo;

- the student's surname, name, patronymic name;

- the full name of educational institution where the student is studying;

- the faculty, the name of the level of higher education, the code number and the name of the speciality;

- labour and pedagogical experience (if any);

- scientific interests.

2. Portrait of the future pedagogue (Form: folder with subfolders):

- the student's resume (life principles, plans for future, prospects for career growth);

- $\quad$ my formula of success;

- $\quad$ love for his/her profession;

- love of children;

- $\quad$ his/her interest in the subject taught in the educational institution.

3. Achievements (Form: folder with subfolders):

- pedagogical experience;

- list of awards, diplomas, letters of commendation (photos); 
- participation in research work, conferences of various levels, olympiads, professional and creative pedagogical competitions, intellectual marathons, etc. (applications, minutes, articles, projects, photos, videos, etc.);

- participation in educational activities of the higher educational institution (the rating of educational activity, lecturers' references, development of notes, reports, abstracts, presentations, certificates of passing of additional educational programs, etc.);

- participation in educational activities during the student's practice in an educational institution (teachers' references, school administration's references, lesson developing notes, master classes, reports at school conferences, parental meetings, presentations, photographs and videos, products, etc.);

- participation in the educational activities of the university (the university administration's references, the faculty administration's references, the curator of the group's references, reports of participation in the educational work of the faculty and the academic group, photographs and videos, wall newspapers, etc.);

- participation in educational activities during the practice in an educational institution (teachers' references, educational institution administration's references, development of notes of the upbringing lessons/classes, presentations, photographic reports of educational activities, etc.).

4. Social/public activity (Form: folder with subfolders):

- participation in ideologicalpolitical, sports, cultural-mass, etc. work (reports and materials testifying to the effectiveness of work: certificates of awards, letters of commendation, appreciation letters, photos and videos, etc.);

- participation in student organisations, associations and societies (description of work, reports in the form of slides, presentations, photos, etc.);

- public missions (reports on the work done, the curator of the group's references, the faculty administration's references, public figures' references, etc.).

5. Evaluations and comments:

- self-analysis and selfassessment of activity;

- commentaries on activities (by students, lecturers, employers, etc.).

6. Additional information (information that will help to reveal personal interests, inclinations, abilities, etc.).

The aforementioned integrated eportfolio has been used in the educational process of the Faculty of PTVE. In the course of our investigation, we have traced the employment of the students as for the beginning of their studying in the fulltime MA course. To do this, the experiment has been conducted on the basis of the SHEI "DSPU" at the faculty of PTVE. 24 respondents from Speciality 011 - Education Sciences, Specialisation "Pedagogics of Higher School" took part in it, among them 14 students entered the experimental 
group (the EG); the control group (the CG) consisted of 10 students.

In order to create a general picture of the future employment of the masters of the Faculty of PTVE, the dispute and interview were held and the respondents' personal affairs were studied.

Consequently, the results of the stating phase of the experiment are the data that are listed in Table 1.

Employment of Future Masters of the Faculty of PTVE

Table 1

(the Stating Phase of the Experiment)

\begin{tabular}{|c|c|c|c|c|c|c|}
\hline \multirow{2}{*}{ Group } & \multicolumn{2}{|c|}{$\begin{array}{c}\text { Working in the } \\
\text { speciality }\end{array}$} & $\begin{array}{c}\text { Not working in } \\
\text { the speciality }\end{array}$ & \multicolumn{2}{l|}{ Not working at all } \\
\cline { 2 - 7 } & $\mathrm{NS}$ & $\%$ & $\mathrm{NS}$ & $\%$ & $\mathrm{NS}$ & $\%$ \\
\hline \hline EG & 2 & 14,3 & 4 & 28,6 & 8 & 57,1 \\
\hline $\mathrm{CG}$ & 3 & 30 & 4 & 40 & 3 & 30 \\
\hline
\end{tabular}

For successful employment of the students at the level of higher education, the Master (Specialiy 011 Education Sciences) it is offered to create and maintain the integrated eportfolios according to the given structure. The study was held during 2016 - 2017 (the period of students' studying is a year and a half).

Since using the e-portfolio requires a considerable amount of time and serious, thorough preparation, working on it was conducted mainly during the extracurricular period of time. The responsible consultants were the curator of the academic group, the head of the department of pedagogy of higher education and a representative of the advisory centre of the faculty of the PTVE.

It should be noted that when working with the e-portfolio, not only the result is important, but also the process of creating a student's own style of work. Developing the eportfolio is a creative process, oriented to the autonomy of choice, imagination, discovery, search, which will make it possible to evaluate independent activity and improve it, to analyse, to generalise and systematise the results of one's own work, objectively evaluate one's own capabilities and plan actions to overcome difficulties and achievement of the best results of pedagogical activity.

The student's e-portfolio makes it possible:

- to introduce the data on participating in scientific-research work; upbringing and educational activities of universities; upbringing and educational activities during the practice in an educational institution;

- to visualise the submitted information (articles, projects, photos, notes, reports, abstracts, presentations, lecturers', teachers' and the educational institution administration's references, etc.);

- to reflect the examples of one's own activities, such as: preparing one's own presentations, creating websites, calling on one's 
own blog, which presents images (diagrams, drawings, photos, videos, etc.), illustrating the process of performing this or that work;

- to demonstrate one's own intellectual abilities, logic of thinking, reflection of the spectrum of actions (participation in scientific-research work, conferences, olympiads, professional and creative pedagogical contests, intellectual marathons), methods the student possesses;

- to monitor the results of the work carried out (references and commentaries on the activities by students, lecturers, representatives of the state employment service, the education department, administrations of educational institutions, etc.

To confirm the effectiveness of using the e-portfolio for the employment of masters of the Faculty of PTVE, Speciality 011 - Education Sciences, Specialisation "Pedagogics of Higher School" it has been conducted the survey: Do you think that for your employment there is enough master's degree diploma?, Do you consider the e-portfolio an effective instrument for your employment?, Have you received any comments, references and suggestions in your blog about job placement in the speciality?, In your opinion, the used e-portfolio needs to be supplemented and changed to improve your employment?

According to the survey conducted among the students of the experimental group, it should be noted that $57.1 \%$ of the respondents call the e-portfolio an effective instrument that has helped them to find work in the speciality; they have received comments, references and suggestions from the representatives of the State Employment Service, the Department of Education, the administration of educational institutions; they also offer to implement creating a web portfolio for conducting correspondence and interviews with potential employers.

The data on the positive dynamics of employment opportunities in the speciality at the forming stage of the experiment (September 2017) are evidenced by the data presented in Table 2.

Employment of Future Masters of the Faculty PTVE

Table 2

(the Pilot Phase of the Experiment)

\begin{tabular}{|c|c|c|c|c|c|c|}
\hline \multirow{2}{*}{ Group } & \multicolumn{2}{|c|}{$\begin{array}{c}\text { Working in the } \\
\text { speciality }\end{array}$} & \multicolumn{2}{c|}{$\begin{array}{c}\text { Not working in the } \\
\text { speciality }\end{array}$} & \multicolumn{2}{c|}{ Not working at all } \\
\cline { 2 - 7 } & NS & $\%$ & NS & $\%$ & NS & $\%$ \\
\hline EG & 8 & 57,1 & 2 & 14,3 & 4 & 28,6 \\
\hline CG & 4 & 40 & 3 & 30 & 3 & 30 \\
\hline
\end{tabular}

It should be noted that two of the four future masters of the EG prepare the documents for admission to the postgraduate course on speciality 011
"Educational, Pedagogical Sciences" in the field of knowledge 01 "Education. Pedagogics" for being the applicants for the third (educational 
and scientific) level of higher education; out of those 8 already working in the speciality: 1 works in a pedagogical college, 7 work in secondary comprehensive educational institutions of the region.

\section{Discussion and conclusions}

A successful career, realising all the accumulated potential during studying and professional training is currently one of the most urgent goals for most graduates. Using the interactive technologies, in particular the e-portfolio, in the process of the training of future professionals in the pedagogical profile is an effective instrument for increasing the competitiveness of the labour market and motivation for employment in the speciality. Using the e-portfolio is a technology of personal and professional development that brings the student closer to his/her future professional activities, enables displaying and certifying his/her actual achievements (educational, professional and personal ones) and records the process of managing his/her professional career.

Consequently, the e-portfolio, which is formed in the process of studying, allows to present the achievements of students in the form of documentary evidence in an orderly and easy-to-use manner (awards, diplomas, letters of commendation; certificates of participation in scientific-research work, conferences, olympiads, professional and creative pedagogical contests, intellectual marathons; data-characteristics of educational and practical training in an educational institution, references and characteristics of the administration of the institution and the faculty concerning participation in the ideological and political, sports, culture-mass and etc. work, in student organisations, associations and societies, etc.). The e-portfolio helps to keep and systematise information about all the achievements in the process of studying at the university, to demonstrate the systematic approach of the graduate to the tasks of his/her career and the high level of business culture.

In the future scientific investigations and studies we plan to consider using the web portfolio for successful employment and to outline the feasibility of its being implemented in the educational process for preparing future pedagogues.

\section{REFERENCES}

1. Ivanova, O. V. (2017). The Use of E-Portfolio to Develop English Language Learners' Autonomy and Independence. Information Technologies and Learning Tools, 60 (4), 155-165. Available at: https://journal.iitta.gov.ua/index.php/itlt/article/view/1677/1208

2. Montgomery, K. K. (2008). Building E-portfolio Using PowerPoint: A Guidefor Educators. London: Sage Publications, 3.

3. The International Society for Technology in Education (ISTE). Available at: http://www.iste.org

4. Bakhmat, N. V. (2014). Modeliuvannia portfolio pedahoha [Modelling Electronic portfolio as a means of successful employment of graduates of pedagogical profile 
the Pedagogue's Portfolio Teaching Manual]. Kamianets-Podilskyi: PP Buinytskyi A. A.

5. Filo, I. Ye. (2011). Tekhnolohiya E-portfolio v profesiyniy pidhotovtsi inzhenernykh fakhivtsiv [Technology "E-Portfolio" in Professional Training of Engineering Professionals]. Teoriya ta metodyka elektronnoho navchannia, 11.

6. Futornyi, S., Gerasimenko, S., Fedorova, M. (2014). Perspektivy primeneniya setevykh elektronnykh portfolio $\mathrm{v}$ formirovanii zdorovogo obraza zhizni studencheskoi molodezhi [Prospects for Applying Networked Electronic Portfolios in Forming Healthy Lifestyle for Student Youth]. Molodizhnyi naukovyi visnyk Skhidnoievropeiskoho natsionalnoho universytetu imeni Lesi Ukrainky. Fizychne vykhovannia i sport, 15, 35-41.

7. Hrabovets, I. V. (2005). Molodi fakhivtsi yak sotsialno-statusna hrupa: kharakterystyka ta rol u systemi suspilnykh vidnosyn [Young Professionals as a Social Status Group: Characteristics and Role in the System of Social Relations]. Hrani, 5, 118-121.

8. Hryzun, L. E. (2012). Elektronne portfolio suchasnoho vchytelia yak zasib pidvyshchennia yoho profesiynoi maisternosti [Electronic Portfolio of a Modern Teacher as a Means of Improving the Professional Skills]. Naukovyi chasopys NPU imeni M. P. Drahomanova. Seriya 16: Tvorcha osobystist uchytelia: problemy teoriyi i praktyky, 17, 162-167.

9. Kononchuk, A. I. (2018). Vykorystannia tekhnolohiyi portfolio u profesiyniyi pidhotovtsi maibutnikh pratsivnykiv sotsialnoi sfery [The use of portfolio technology in the training of the future social workers]. Visnyk Chernihivskoho natsionalnoho pedahohichnoho universytetu im. T. H. Shevchenka, 150, 70-74. Available at: http://visnyk.chnpu.edu.ua/?p=705

10. Lisohor, L. S. (2009). Pratsevlashtuvannia vypusknykiv v umovakh ekonomichnoi kryzy [Employment of Graduates Under Conditions of Economic Crisis]. Demohrafiya ta sotsialna ekonomika, 2, 58-67.

11. Molchanova, Z. M., Timchenko, A. A., Chernikova, T. V. (2007). Lichnostnoe portfolio starsheklassnika [Personal Portfolio of a Senior Pupil]. Moscow: Globus.

12. Morze, N. V., Varchenko-Trotsenko, L. O. (2014). Elektronne portfolio yak instrument vymiriuvannia rezultativ diyalnosti vykladacha suchasnoho VNZ [Electronic Portfolio as an Instrument for Measuring the Results of a Lecturer's Activity of Modern University]. Informatyka ta informatsiyni tekhnolohiyi $\mathrm{v}$ navchalnykh zakladakh, 53, 36-41.

13. Petrenko, L. M. (2016). Elektronnyi portfolio: vid tekhnolohiyi profesiynoho navchannia do tekhnolohiyi samoreklamy na rynku pratsi [Electronic Portfolio: from Technology of Professional Training to Technology of Self-Promotion at the Labour Market]. Naukovyi visnyk Instytutu profesiynotekhnichnoi osvity NAPN Ukrainy. Seriya: Profesiyna pedahohika, 11, 63-71.

14. Smolianinova, O. G., Bekuzarova, N. V. (2012). Perspektivy ispolzovaniia tekhnologii e-portfolio dlia trudoustroistva (itogi ekspertnogo seminara) [Prospects for Using E-Portfolio Technology for Employment (O) Saiapina S. A., Korkishko O. H., 2018 
(Results of the Expert Seminar)]. Sovremennye problemy nauki i obrazovaniya, 6. Available at: https://www.science-education.ru/ru/article/view?id=7400

15. State Statistics Service of Ukraine. Available at: http://www.ukrstat.gov.ua

16. Zhytienova, N. (2017). E-portfolio as a tool of self-presentation of the future specialist. Open educational e-environment of modern university, 3, 212-219. doi: https://doi.org/10.28925/2414-0325.2017.3.21219

САЯПІНА, С. А. - доктор педагогічних наук, доцент, професор кафедри педагогіки вищої школи, ДВНЗ «Донбаський державний педагогічний університет» (Слов'янськ, Україна).

E-mail: Sayapina.s.a.2018@gmail.com, ORCID ID 0000-0001-5808-7020

КОРКІШКО, О. Г. - кандидат педагогічних наук, доцент, доцент кафедри педагогіки вищої школи, ДВНЗ «Донбаський державний педагогічний університет (Слов'янськ, Україна)

E-mail: Korkishko.l.g@gmail.com, ORCID ID 0000-0001-7341-2610

\section{ЕЛЕКТРОННЕ ПОРТФОЛІО ЯК ЗАСІБ УСПІШНОГО ПРАЦЕВЛАШТУВАННЯ ВИПУСКНИКІВ ПЕДАГОГІЧНОГО ПРОФІЛЮ}

Анотація. У статті розглянуто проблему розробки та застосування електронного портфоліо з погляду впливу на успішне працевлаштування майбутнього педагога. Доведено актуальність його використання для коректної самореклами майбутніх фахівців педагогічного профілю на сучасному ринку праці, що сприятиме підвищенню конкурентоспроможності та мотивації на працевлаштування за фахом.

Зазначено, що е-портфоліо майбутнього спеціаліста - це коректна самореклама, у якій представлено різноманітну інформацію про наявний рівень професійної підготовки студента, що дозволяє об'єктивно оцінювати його потенціал як спеціаліста потенційними роботодавцями.

3'ясовано, що е-портфоліо може слугувати інструментом вимірювання якості підготовки майбутнього спеціаліста за допомогою оцінювання кількісних (участь у науково-дослідній роботі, наукових і науковопрактичних конференціях різного рівня, олімпіадах з предметів, конкурсах наукових робіт, суспільному житті вишу та міста; друковані та електронні публікації тощо) i якісних (відгуки однокурсників i викладачів, рекомендаційні листи, грамоти, відзиви керівника практики та керівництва навчального закладу, рейтинг успішності навчання тощо) показників його діяльності.

Electronic portfolio as a means of successful employment of graduates of pedagogical profile 
Показано, що для успішного працевлаштування випускників найбільш ефективними є комплексні е-портфоліо, що становлять сукупність різних блоків, як-от: загальні відомості про студента; портрет педагога; досягнення; суспільна діяльність; оцінювання та коментарі.

Акцентовано, що е-портфоліо студента уможливило: внесення інформації про участь у науково-дослідній, навчальній та виховній діяльності ВНЗ; візуалізацію поданої інформації; відбиття прикладів власної діяльності, ілюстрування процесу виконання тієї чи тієї роботи; демонстрування власних інтелектуальних здібностей, логіки мислення, відображення спектра дій, методів, якими вони володіють; моніторинг результатів проведеної роботи.

Ключові слова: е-портфоліо; працевлаштування; студент; майбутній магістр; педагогічний профіль; факультет.

САЯПИНА, С. А. - доктор педагогических наук, доцент, профессор кафедры педагогики высшей школы, ГВУЗ «Донбасский государственный педагогический университет» (Славянск, Украина)

E-mail: Sayapina.S.a.2018@gmail.com,ORCID ID 0000-0001-5808-7020

КОРКИШКО, Е. Г. - кандидат педагогических наук, доцент, доцент кафедры педагогики высшей школы, ГВУЗ «Донбасский государственный педагогический университет» (Славянск, Украина)

E-mail: Korkishko.l.g@gmail.com,ORCID ID 0000-0001-7341-2610

\section{ЭЛЕКТРОННОЕ ПОРТФОЛИО КАК СРЕДСТВО УСПЕШНОГО ТРУДОУСТРОЙСТВА ВЫПУСКНИКОВ ПЕДАГОГИЧЕСКОГО ПРОФИЛЯ}

Аннотация. В статье рассмотрена проблема разработки и применения электронного портфолио с точки зрения влияния на успешное трудоустройство будущего педагога.

Доказана актуальность его использования для корректной саморекламы будущих специалистов педагогического профиля на современном рынке труда, что будет способствовать повышению конкурентоспособности и мотивации на трудоустройство по специальности.

Отмечено, что э-портфолио будущего специалиста - это корректная самореклама, в которой представлена разнообразная информация об имеющемся уровне профессиональной подготовки студента, позволяющая объективно оценивать его потенциал как специалиста.

Выяснено, что э-портфолио может служить инструментом измерения качества подготовки будущего специалиста с помощью оценки количественных (участие в научно-исследовательской работе, научных и (C) Saiapina S. A., Korkishko O. H., 2018 
научно-практических конференциях разного уровня, олимпиадах по предметам, конкурсах научных работ, общественной жизни вуза и города; печатные и электронные публикации и т.д.) и качественных (отзывы однокурсников и преподавателей, рекомендательные письма, грамоты, отзывы руководителя практики и руководства учебного заведения, рейтинг успеваемости и т.д.) показателей его деятельности.

Показано, что для успешного трудоустройства выпускников наиболее эффективны комплексные э-портфолио, представляющие собой совокупность различных блоков, таких как: общие сведения о студенте; портрет педагога; достижения; общественная деятельность; оценка и комментарии.

Акцентировано, что э-портфолио студента способствует: внесению информации об участии в научно-исследовательской, учебной и воспитательной деятельности вуза; визуализации представленной информации; отражению примеров собственной деятельности, иллюстрации процесса выполнения работы; демонстрации собственных интеллектуальных способностей, логики мышления, отражение спектра действий, методов, которыми они обладают; мониторингу результатов проведенной работы.

Ключевые слова: э-портфолио; трудоустройство; студент; будущий магистр; педагогический профиль; факультет.

Стаття рекомендована до публікачії д.філософ.н., проф. Р.І.Олексенко (Мелітополь, Україна)

Надійшла до редколегіï: 10.11.2018 р. Прийнята до друку: 15.11.2018 p. 